Provided for non-commercial research and education use. Not for reproduction, distribution or commercial use.

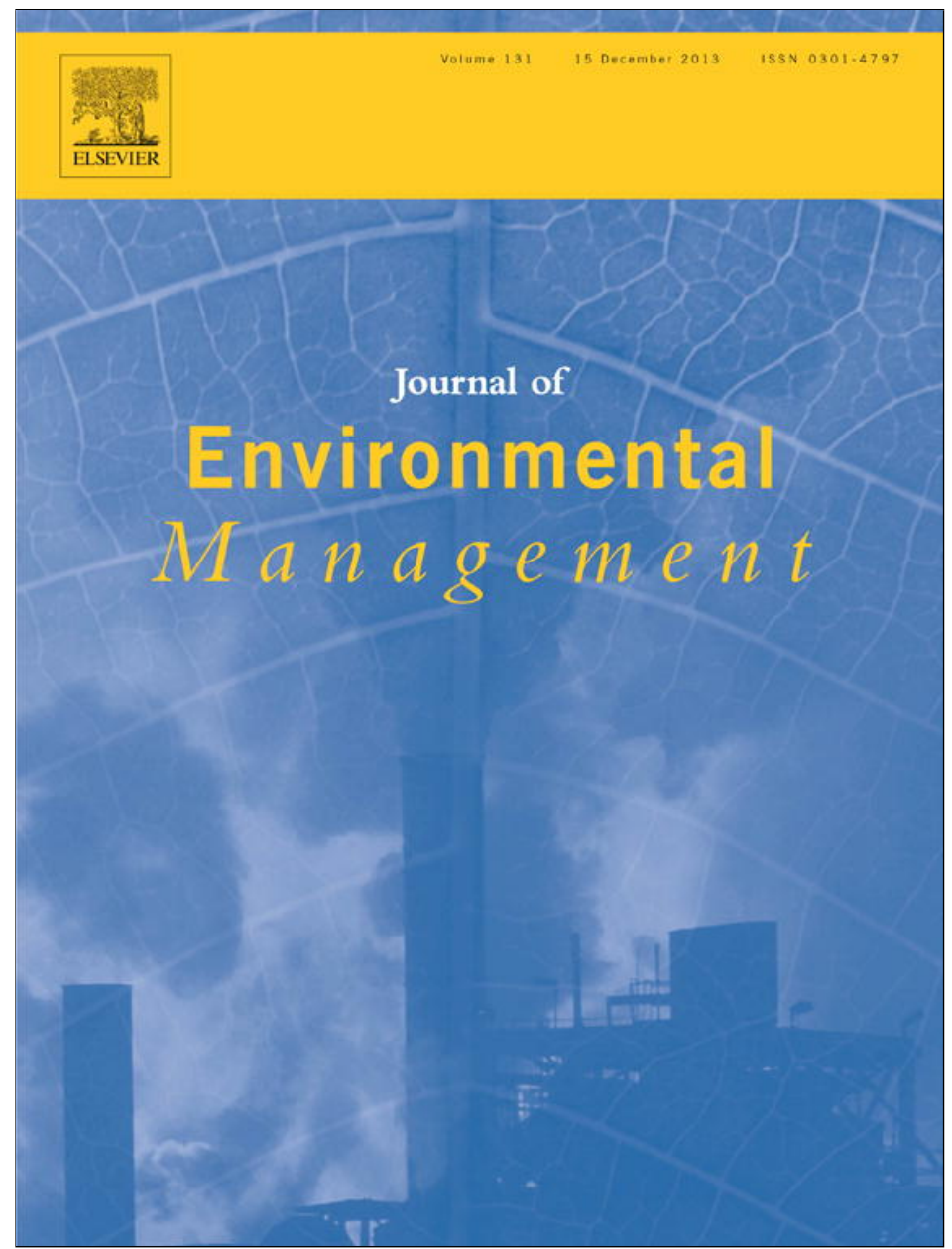

This article appeared in a journal published by Elsevier. The attached copy is furnished to the author for internal non-commercial research and education use, including for instruction at the authors institution and sharing with colleagues.

Other uses, including reproduction and distribution, or selling or licensing copies, or posting to personal, institutional or third party websites are prohibited.

In most cases authors are permitted to post their version of the article (e.g. in Word or Tex form) to their personal website or institutional repository. Authors requiring further information regarding Elsevier's archiving and manuscript policies are encouraged to visit:

http://www.elsevier.com/authorsrights 


\title{
Removal of groundwater arsenic using a household filter with iron spikes and stainless steel
}

\author{
M. Avilés ${ }^{a}$, S.E. Garrido ${ }^{\text {a }}$, M.V. Esteller ${ }^{\text {b,* }}$, J.S. De La Paz ${ }^{\text {a }}$, C. Najera ${ }^{\text {a }}$, J. Cortés ${ }^{\text {a }}$ \\ ${ }^{a}$ Instituto Mexicano de Tecnología del Agua (IMTA), Paseo Cuauhnáhuac 8532, Progreso, Jiutepec, Mexico \\ ${ }^{\mathrm{b}}$ Centro Interamericano de Recursos del Agua (CIRA), Facultad de Ingeniería, Universidad Autónoma del Estado de México, Cerro Coatepec S/N, \\ 50130 Toluca, Mexico
}

\section{A R T I C L E I N F O}

\section{Article history:}

Received 4 September 2012

Received in revised form

11 September 2013

Accepted 23 September 2013

Available online 22 October 2013

\section{Keywords:}

Water quality

Arsenic

Removal

Iron

Household filter

\begin{abstract}
A B S T R A C T
Arsenic (As) in groundwater for domestic use poses a worldwide threat to public health, most notably in rural areas. The aims of this study were: first, determine groundwater composition in a mining area in central Mexico (Huautla); second, assess As exposure through human groundwater consumption and; third, develop and test a household filter to obtain drinking water for these rural communities.

From the 17th century through the 1990s, mines in the area produced Ag-galena and sphalerite from volcanic rock. Groundwater flooded the mines when they were abandoned due to low silver prices. Local households now use the water to meet domestic needs. Water from the mines was found to have high As content $\left(0.04-0.26 \mathrm{mg} \mathrm{L}^{-1}\right)$ and $\mathrm{Fe}, \mathrm{Mn}, \mathrm{Pb}$ and $\mathrm{Cd}$ were also above Mexican drinking water standards and WHO guidelines. All the population in the Huautla community was exposed to the metalloid through water used in food preparation.

The best As removal was obtained with a filter using oxidized commercial fiber ( $\mathrm{HCl} 2 \mathrm{~N}$ as oxidant). Concentrations in the effluent were below Mexican drinking water standards ( $0.025 \mathrm{mg} \mathrm{As} \mathrm{L}^{-1}$ water) during the 105-day $(2520 \mathrm{~h})$ filter operation, with a maximum As removal efficiency of $95.4 \%$. The household filter was simple, low-cost and may be very attractive for As removal in rural areas in developing countries.
\end{abstract}

(c) 2013 Elsevier Ltd. All rights reserved.

\section{Introduction}

In Mexico, arsenic in groundwater is becoming a problem in regions such as La Comarca Lagunera, Salamanca, San Luis Potosi and Zimapan, among many others (Rodriguez et al., 2004; Armienta and Segovia, 2008). Its presence is associated with natural and anthropogenic sources and its origin in mining areas is frequently linked to naturally high arsenic levels in rock, extraction and processing of ores and leaching of tailings (Rodriguez et al., 2004; Iavazzo et al., 2012). Moreover, abandoned mines typically were flooded due to rising groundwater and it is possible, therefore, to occur significant arsenic concentrations. Because of ready availability, water in flooded mines is used as drinking water and for livestock.

Health hazards stem from the use of water containing arsenic for drinking and cooking. Since these activities account for only a small percent of total domestic water consumption, this strongly

\footnotetext{
* Corresponding author. Tel./fax: +52 7221806191.

E-mail addresses: mvestellera@uaemex.mx, vicenta13@prodigy.net.mx (M.V. Esteller).
}

suggests that it is economically attractive to remove arsenic only from water used for drinking and cooking. Arsenic removal should consequently be done at the household level with point-of-use systems. This approach would be particularly effective in rural communities lacking centralized water supply systems.

\subsection{As removal technologies}

Different treatment technologies to reduce concentrations of arsenic in drinking water are available or under investigation. Some of these include coagulation-sedimentation-filtration, nanofiltration, reverse osmosis, fluidized-bed sand reactor, and subsurface groundwater treatment (Mohan and Pittman, 2007; Pokhler and Viraraghavan, 2009). Nevertheless, these technologies are inappropriate for application in rural communities especially in Bangladesh, West Bengal, India, Vietnam, Taiwan, Inner Mongolia, Hungary, Romania and Latin America where arsenicrelated problems are most pronounced (Berg et al., 2006; Sarkar et al., 2008; Pokhler and Viraraghavan, 2009).

There are a variety of household-level arsenic removal technologies, including adsorption onto iron and/or manganese oxides, 
activated alumina filters and different coagulation-sedimentation-filtration bucket treatment units (Petrusevski et al., 2002; Driehaus, 2002; Leupin and Hug, 2005; Giles et al., 2011). According to Ngai et al. (2007), more than 50 household treatment technologies exist worldwide.

Simple filters with iron in various forms - such as filings, turnings, or nails - have shown great promise for some years in Bangladesh (Hussam and Munir, 2007).

The well-head unit, for example, is a simple type of filter described by Sarkar et al. (2008) in which entering water passes over a splash plate, then droplets formed subsequently become oxygenated, and during the second removal process activated alumina and/or an arsenic-selective hybrid anion exchanger (HAIX) acts as a regenerable sorbent material. The 2-Kolshi System (Ngai et al., 2007) removes arsenic by co-precipitation and filtration mechanisms. This consists of a 20 -L plastic mixing bucket, a filtration unit comprised of two ceramic pots and chemical packets containing ferric chloride (as a coagulant), calcium hypochlorite (as an oxidant and disinfectant) and charcoal powder (as an adsorbent).

In the KanchanTM Arsenic Filter (KAF) (Ngai et al., 2006), air serves as an oxidant and zero-valent iron as a sorption media in the filter. $\mathrm{Fe}(\mathrm{III})(\mathrm{hydr})$ oxides with high As-sorption capacity are formed. The filter material -such as iron metal- is cheap and available even in rural villages in developing countries. The efficiency of arsenic removal with this filter was $88-95 \%$. The KAF is also considered to be a Biosand Filter (BSF). Unlike a simple sand filter which removes particles by mechanical straining only, a BSF has the capacity to remove pathogens as well.

The KAF is a modified slow sand filter with additional arsenic removal capacity, consisting of a plastic or concrete container filled with gravel, sand and iron nails. At the top of the filter, nongalvanized iron nails are exposed to air and water and thereby rust quickly, producing ferric hydroxide on the surface of the nails, which absorbs arsenic from the water. Some arsenic-loaded iron particles are flushed onto the sand layer below and are trapped in the top few centimeters of the fine sand due to straining (Ngai et al., 2007). As ferric hydroxide particles "exfoliate" from the iron nails, new iron surfaces are created, providing additional arsenic adsorption capacity (Ngai et al., 2006).

The 3-Kolshi System/SONO Filter was initially developed by the SONO Diagnostic Center in Bangladesh and consists of three clay pots stacked vertically. It is based on an indigenous water treatment practice, as described by Hussam and Munir (2007) who developed and produced the SONO filters (Ngai et al., 2007). Arsenic is removed by adsorption to iron filings contained in the top of the pot. Ongoing improvement of the filter system has led to a new filter model, the SONO45-25 filter. The efficiency of arsenic removal obtained with this filter was 90-99\%.

In the 2-Kolshi System arsenic is removed by co-precipitation and filtration mechanisms. This consists of a $20-\mathrm{L}$ plastic mixing bucket, a filtration unit comprised of two ceramic pots and chemical packets containing ferric chloride (as coagulant), calcium hypochlorite (as oxidant and disinfectant), and charcoal powder (as adsorbent) arsenic removal with this system was 80-95\% (Ngai et al., 2007).

\subsection{Study site}

The study area is known as the Huautla Mining District. It is located in the southern part of the State of Morelos, central Mexico (Fig. 1), between $18^{\circ} 40^{\prime} \mathrm{N}$ and $18^{\circ} 20^{\prime} \mathrm{N}$ and $90^{\circ} 10^{\prime} \mathrm{W}$ and $90^{\circ} 50^{\prime} \mathrm{W}$, at $911 \mathrm{~m}$ above sea level. The climate is warm and subhumid with $22.3{ }^{\circ} \mathrm{C}$ annual mean temperature and $867.5 \mathrm{~mm}$ precipitation.

Exploitation of silver contained in galena $(\mathrm{PbS})$ and sphalerite (ZnS) started in the 17th century. Other metals of economic interest produced from the mines included $\mathrm{Cu}, \mathrm{Pb}, \mathrm{Zn}$ and $\mathrm{Au}$. The geology is characterized by Tertiary volcanic rocks of intermediate composition such as andesites, dacites and trachites in the form of lava flows and volcanoclastic deposits. Ore minerals are present as filling in faults with predominantly east-west direction, generally with tectonic breccias. Solutions enriched in silica produced sinter formations which became clay deposits with high iron content. These were subsequently replaced by calcite (Camprubi and Albison, 2006). The main minerals exploited in the district were Argentite, stromeyerite, argentiferous galena, sphalerite, malachite, azurite, cerussite and native silver. The main economic minerals were argentite, stromeyerite and argentiferous galena and accessory minerals were barite, quartz, amethyst quartz, pyrite and calcite.

Mining ceased at the end of the 1990s due to low silver prices. Mines were abandoned without maintenance and tunnels flooded. Water from abandoned mines is used by the population of Huautla (1200 inhabitants) to meet domestic and livestock needs, as water supply is problematic in the region.

The aims of this study were: first, to investigate the physicochemical characteristics of arsenic-contaminated groundwater and their relation with geological media; second, to evaluate the

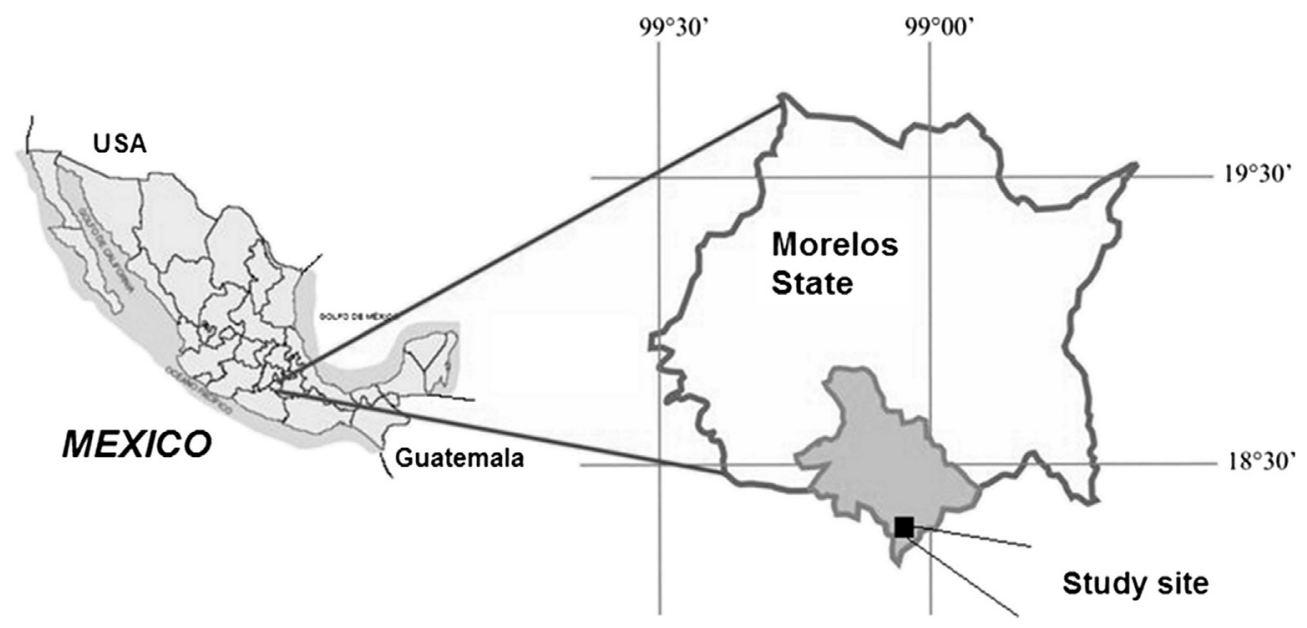

Fig. 1. Location map of the study area. State of Morelos (Central Mexico). 
exposure of the population to groundwater arsenic and; third, to develop a household filter using locally available materials such as iron spikes, commercial fiber (stainless steel material to remove grease and residue), fine gravel and sand.

\section{Materials and methods}

\subsection{Water quality analyses}

In 2006-2007, 12 groundwater samples were collected from the workings of four abandoned mines (Pajaro Verde, Presita, Santiago and Tlachichilpa), according to Mexican standard NOM 230-SSA12002. Temperature, pH, electric conductivity (EC) and redox potential (Eh) were determined in the field using portable equipment (Checkmate Hand-Held Analysis System).

The samples were filtered $(0.45 \mu \mathrm{m}$ disk filter) and nitric acid was added to aliquots for cation analysis. The samples were stored in a refrigerator at $4{ }^{\circ} \mathrm{C}$. These measurements followed Mexican guidelines and used APHA (2005) methods. Alkalinity and chloride concentration were determined by titration, sulfate and nitrate by spectrophotometry, and major cations $\left(\mathrm{Ca}^{2+}, \mathrm{Mg}^{2+}, \mathrm{Na}^{+}, \mathrm{K}^{+}, \mathrm{Mn}\right.$ and $\mathrm{Si}$ ) by atomic absorption spectrometry. Heavy metals were analyzed using a graphite furnace atomic absorption spectrophotometer. Total As content was determined by two methods using: the Wagtech Arsenator ${ }^{\circledR}$ field kit (Garrido et al., 2009) and atomic absorption spectrophotometry (Perkin Elmer Model 3100 equipped with a hydride generator).

PHREEQC software (Parkhurst and Appelo, 1999) was used to predict the redox state of As species (As III or As V). Calculations were performed with water with a charge balance of $<5 \%$.

\subsection{Preliminary appraisal of As health exposure}

The population's potential health risk due to exposure to As was calculated. The route of exposure included ingestion and skin contact; short and long periods of exposure were considered. This preliminary appraisal of arsenic exposure followed USEPA guidelines (1991), which involved identification of contaminant sources, magnitude of exposure, pathways of population exposure and characterization of risk. Information was obtained from residents $2-78$ years old with particular interest in developing individuals; the questionnaire for children was administered to their mothers. Foremost in the items of the questionnaire were: water (bottled or well water) consumed by children, mothers and other adults; type of water used to prepare food; length of residence in the community; frequency of gastrointestinal diseases and; the presence of skin diseases on hands, face and feet.

\subsection{Arsenic removal test}

The Instituto Mexicano de Tecnología del Agua (Mexican Institute for Water Technology, IMTA, Spanish acronym) has developed an arsenic removal system (Fig. 2) which uses adsorption/co-precipitation with iron nails and a commercial fiber (stainless steel material to remove kitchen grease and residue) followed by sand filtration (sand diameter $0.28-0.45 \mathrm{~mm}$ and TE of $1.2 \mathrm{~mm}$ ).

The inner diameter of acrylic columns were $0.14 \mathrm{~m}$ (adsorption column) and $0.09 \mathrm{~m}$ (filtration column). The heights of the beds were $0.20 \mathrm{~m}$ for gravel and $0.22 \mathrm{~m}$ for sand-gravel. The filter area measured $6.35 \cdot 10^{-3} \mathrm{~m}^{2}$. The flow control valves and sampling points were P1 - Water influent, P2 - Adsorbent media effluent, P3 - Gravel filter effluent, and P4 - Sand-gravel filter effluent (Fig. 2). These two units were operated in the following conditions:

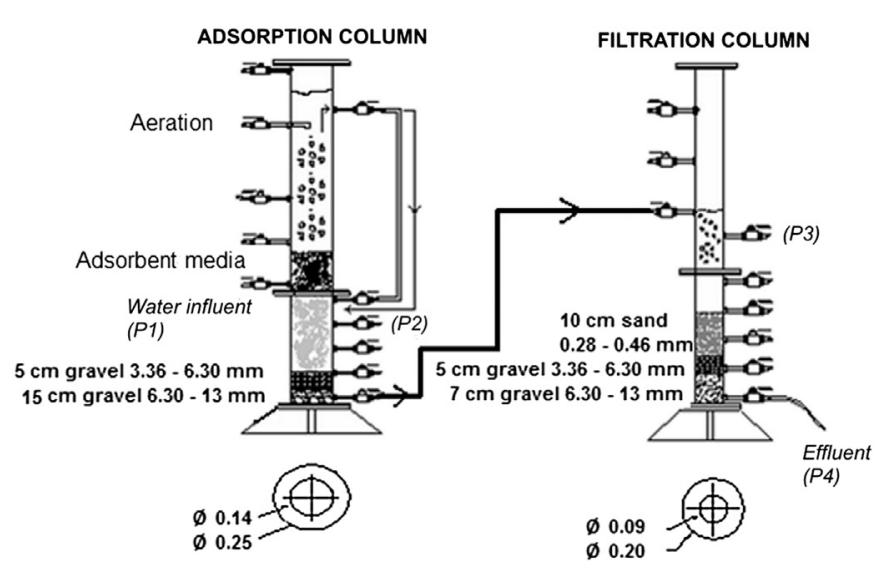

Fig. 2. Typical schematic configuration filters.

1) Adsorption column: filtration rate of $0.078 \mathrm{~m} \mathrm{~h}^{-1}$ and contact time of $76 \mathrm{~min}$

2) Filtration column: filtration rate of $0.189 \mathrm{~m} \mathrm{~h}^{-1}$, capacity sufficient to cover daily water consumption $\left(28.8 \mathrm{~L} \mathrm{~d}^{-1}\right)$ for drinking and cooking.

The first configuration (Experiment 1) used a $2.2 \mathrm{~kg}$ iron nails bed oxidized with $\mathrm{HNO}_{3} 4.8 \mathrm{~N}$ solution. The second configuration (Experiment 2) used a $181.3 \mathrm{~g}$ commercial fiber bed oxidized with $500 \mathrm{~mL} \mathrm{HNO}_{3} 4.8 \mathrm{~N}$ solution. Finally the third configuration (Experiment 3) used a $181.3 \mathrm{~g}$ commercial fiber bed oxidized with $500 \mathrm{~mL} \mathrm{HCl} 2 \mathrm{~N}$ solution. The equations for hydrochloric and nitric acid reactions with iron are:

$2 \mathrm{HCl}+\mathrm{Fe} \rightarrow \mathrm{FeCl}_{2}+\mathrm{H}_{2}$

$10 \mathrm{HNO}_{3}+4 \mathrm{Fe} \rightarrow 4 \mathrm{Fe}\left(\mathrm{NO}_{3}\right)_{2}+\mathrm{N}_{2} \mathrm{O}+5 \mathrm{H}_{2} \mathrm{O}$

The arsenic removal tests were performed with water from the Pajaro Verde site, where As (III) was present in small quantities (Garrido et al., 2009). Fortunately, all As (III) was oxidized in sodium hypochlorite solution $\left(1 \mathrm{mg} \mathrm{L}^{-1}\right)$ into the more stable As $(\mathrm{V})$ for better treatment efficiencies. The ambient temperature during the trials ranged from 19 to $21^{\circ} \mathrm{C}$ throughout the test. The $\mathrm{pH}$ was kept constant at a value of 8.6 .

\section{Results and discussion}

\subsection{Chemical composition of waters}

The chemical composition of water samples is summarized in Table 1. Groundwater had an electric conductivity of up to $192 \mu \mathrm{S} \mathrm{cm}^{-1}$, which corresponded to $\mathrm{HCO}_{3}{ }^{-}\left(338 \mathrm{mg} \mathrm{L}{ }^{-1}\right), \mathrm{Ca}^{2+}$ $\left(65 \mathrm{mg} \mathrm{L}^{-1}\right), \mathrm{Mg}^{2+}\left(29 \mathrm{mg} \mathrm{L}^{-1}\right)$ and $\mathrm{Na}^{+}\left(47 \mathrm{mg} \mathrm{L}^{-1}\right)$ contents. The $\mathrm{Ca}^{2+}$ and $\mathrm{Mg}^{2+}$ contents correlated well with the $\mathrm{HCO}_{3}{ }^{-}$content $(r=0.916)$. Major element concentrations were plotted on a Piper diagram and showed only small variations, especially in cation concentrations. Groundwater was basically bicarbonate water, and calcium and sodium were the prevailing cations (Fig. 3). According to a preliminary hydrogeochemical groundwater model (Esteller et al., 2010), groundwater composition was related to volcanic rock. Rainwater infiltration and water-rock interaction could explain the presence of $\mathrm{HCO}_{3}^{-}$as a dominant anion and neutral $\mathrm{pH}$ conditions (Appelo and Potsm, 2005). The dominance of bicarbonate may partly reflect calcite in veins.

Concentrations of $\mathrm{As}, \mathrm{Fe}, \mathrm{Mn}, \mathrm{Cd}$ and $\mathrm{Pb}$ species were higher than Mexican drinking water standards (NOM-127-SSA1-1994). 
Table 1

Results of the physicochemical analyses of groundwater samples (values in $\mathrm{mg} \mathrm{L}^{-1}$, except $\mathrm{EC}\left(\mu \mathrm{S} \mathrm{cm}{ }^{-1}\right)$, Eh $(\mathrm{mV}), \mathrm{T}\left({ }^{\circ} \mathrm{C}\right)$, pH; EC: electric conductivity, TDS: total dissolved solids, Nd: not determined).

\begin{tabular}{|c|c|c|c|c|c|c|c|c|c|c|c|c|c|}
\hline & Mexican standards & Pajaro & Pajaro & Pajaro & Pajaro & Presita & Presita & Santiago & Santiago & Santiago & Tlachichi & Tlachichi & Tlachichi \\
\hline & & Aug-06 & Feb-07 & Jul-07 & May-06 & Jul-07 & May-07 & Feb-07 & Jul- 07 & May-06 & May-06 & Jul-07 & Feb-07 \\
\hline $\mathrm{pH}$ & $6.5-8.5$ & $\mathrm{Nd}$ & 7.63 & 7.67 & 7.33 & 7.19 & 7.2 & 7.46 & 7.35 & 7.16 & $\mathrm{Nd}$ & 7.52 & 7.4 \\
\hline Eh & - & $\mathrm{Nd}$ & 146.3 & $\mathrm{Nd}$ & 256.4 & $\mathrm{Nd}$ & $\mathrm{Nd}$ & 149.9 & $\mathrm{Nd}$ & 57.8 & $\mathrm{Nd}$ & $\mathrm{Nd}$ & 187.3 \\
\hline $\mathrm{T}^{\mathrm{a}}$ & - & $\mathrm{Nd}$ & $\mathrm{Nd}$ & $\mathrm{Nd}$ & 26 & $\mathrm{Nd}$ & $\mathrm{Nd}$ & 25.5 & $\mathrm{Nd}$ & 24 & $\mathrm{Nd}$ & $\mathrm{Nd}$ & 21.9 \\
\hline EC & - & $\mathrm{Nd}$ & 437 & $\mathrm{Nd}$ & 486 & $\mathrm{Nd}$ & $\mathrm{Nd}$ & 514 & $\mathrm{Nd}$ & 558 & $\mathrm{Nd}$ & $\mathrm{Nd}$ & 192 \\
\hline TDS & - & $\mathrm{Nd}$ & 484 & 396 & 356 & 468 & 403 & 506 & 442 & 348 & Nd & 242 & 298 \\
\hline $\mathrm{Na}^{+}$ & - & 34.31 & 31.19 & 32.97 & 25.12 & 46.87 & 41.83 & 35.22 & 36.89 & 27.23 & 20.81 & 11.1 & 9.48 \\
\hline $\mathrm{K}^{+}$ & - & 3.44 & 3.01 & 2.36 & 2.03 & 6.12 & 2.44 & 2.358 & 5.51 & 5.35 & 2.75 & 3.75 & 3.53 \\
\hline $\mathrm{Mg}^{2+}$ & - & 3.06 & 14.126 & 17.6 & 15.11 & 28.94 & 25.8 & 14.157 & 17.36 & 16.21 & 8.66 & 7.66 & 5.45 \\
\hline $\mathrm{Ca}^{2+}$ & - & 35.49 & 42.59 & 49.54 & 48.71 & 55.11 & 51.83 & 54.55 & 65.04 & 62.58 & 25.6 & 29.61 & 21.72 \\
\hline $\mathrm{Cl}^{-}$ & - & 3.6 & 1.51 & 4.43 & 2.46 & 6.89 & 6.12 & 6.54 & 6.4 & 7.88 & 1.18 & 0.936 & 1.51 \\
\hline $\mathrm{SO}_{4}^{2-}$ & 400 & 8.43 & 9.98 & 11.5 & 5.65 & 5.1 & $\mathrm{Nd}$ & 39.6 & 43.6 & 43.3 & 5.65 & 7.91 & 7.19 \\
\hline $\mathrm{NO}_{3}^{-}$ & 40 & 11.07 & $\mathrm{Nd}$ & 6.29 & 17.05 & 3.96 & 6.51 & 0.9 & 0.91 & 0.9 & 7.3 & 3.89 & 5.36 \\
\hline $\mathrm{HCO}_{3}^{-}$ & 250 & 221 & 228 & 248 & 289 & 338 & 319 & 251 & 265 & 315 & 132 & 119 & 114.8 \\
\hline $\mathrm{Si}$ & - & $\mathrm{Nd}$ & 22.36 & 14.31 & 14.46 & 15.68 & 20.87 & 13.405 & 9.33 & 7.73 & $\mathrm{Nd}$ & 9.43 & 16.24 \\
\hline As & 0.025 & 0.098 & 0.122 & 0.1334 & 0.083 & 0.0417 & 0.0501 & 0.0877 & 0.1102 & 0.049 & 0.261 & 0.2324 & 0.2614 \\
\hline Mn & 0.15 & $\mathrm{Nd}$ & 0.05 & 0.05 & 0.05 & 0.05 & 0.05 & 1.56 & $\mathrm{Nd}$ & 1.64 & 0.05 & 0.05 & 0.05 \\
\hline $\mathrm{Fe}$ & 0.30 & $\mathrm{Nd}$ & 0.083 & 0.05 & 0.05 & 0.05 & 0.05 & 0.232 & 0.8 & 0.13 & 0.05 & 0.118 & 0.536 \\
\hline $\mathrm{F}^{-}$ & 1.50 & 0.32 & 0.307 & 0.507 & 0.3 & 0.45 & 1.45 & 0.412 & 0.623 & 0.439 & 0.52 & 0.514 & 0.334 \\
\hline $\mathrm{Cd}$ & 0.005 & $\mathrm{Nd}$ & 0.0016 & 0.001 & 0.001 & $\mathrm{Nd}$ & 0.001 & 0.0019 & 0.0109 & 0.0017 & 0.0066 & 0.001 & 0.001 \\
\hline $\mathrm{Pb}$ & 0.01 & $\mathrm{Nd}$ & 0.005 & 0.005 & 0.01 & 0.005 & 0.0168 & 0.1193 & 1.3390 & 0.046 & 0.2669 & 0.005 & 0.005 \\
\hline
\end{tabular}

Fig. 4 shows As concentrations in all samples exceeding the current WHO guideline $\left(0.010 \mathrm{mg} \mathrm{L}^{-1}\right)$ as well as Mexican drinking water standards $\left(0.025 \mathrm{mg} \mathrm{L}^{-1}\right)$. High contents of As, Cd and $\mathrm{Pb}$ species dissolved in groundwater are commonly attributed to dissolution of galena, sphalerite and pyrite (Smedley and Kinniburgh, 2002; Seiler, 2004). These minerals have been identified in ore within the study area (Schulze, 1959).

Most relevant to this study, bicarbonate and silicate have been found to interfere with arsenic sorption onto iron oxides and hydroxides (McNeil et al., 2002; Smedley and Kinniburgh, 2002; Gao et al., 2011). Thus, higher bicarbonate and silicate levels in

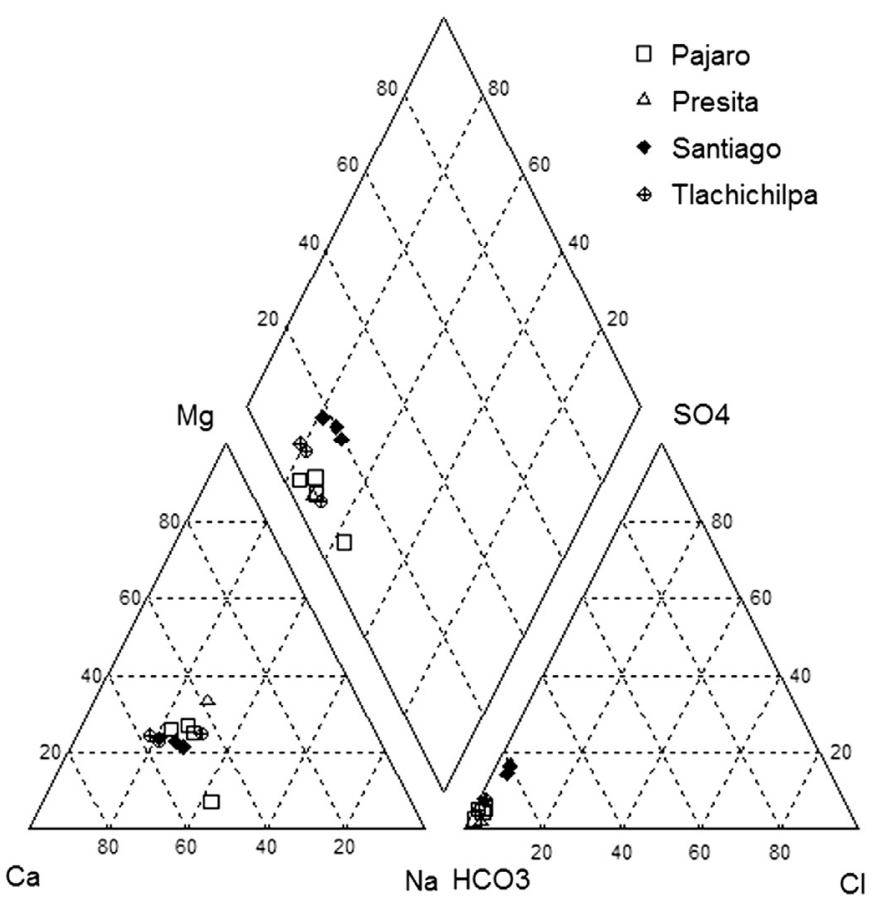

Fig. 3. Piper diagram showing major ion composition of groundwater samples. The groundwater was type $\mathrm{Ca}-\mathrm{HCO}_{3}$. groundwater coupled with higher $\mathrm{pH}$ (Table 1) can increase dissolved As concentrations (Gao et al., 2011). This process could explain the high groundwater As concentration values in the study area.

According to As speciation performed with PHREEQC, As (V) concentration $\left(10^{-7}-10^{-6} \mathrm{~mol} \mathrm{~L}^{-1}\right)$ was greater than As (III) $\left(10^{-19}-10^{-9} \mathrm{~mol} \mathrm{~L}^{-1}\right)$.

\subsection{Risk assessment}

Ninety-three questionnaires were distributed to willing residents in the study area (92 valid replies and one no-reply); 57 participants were women and 35 men. The survey showed that all residents of the Huautla community were exposed to the metalloid through water used for food preparation. In addition, $43.0 \%$ of the population had a high exposure to arsenic, as their only drinking water supply was from the mine area. A smaller group, $11.8 \%$, had intermediate exposure since they consumed both water from the mine area and bottled water. Finally, $45.2 \%$ ingested only bottled water, suggesting a very low exposure.

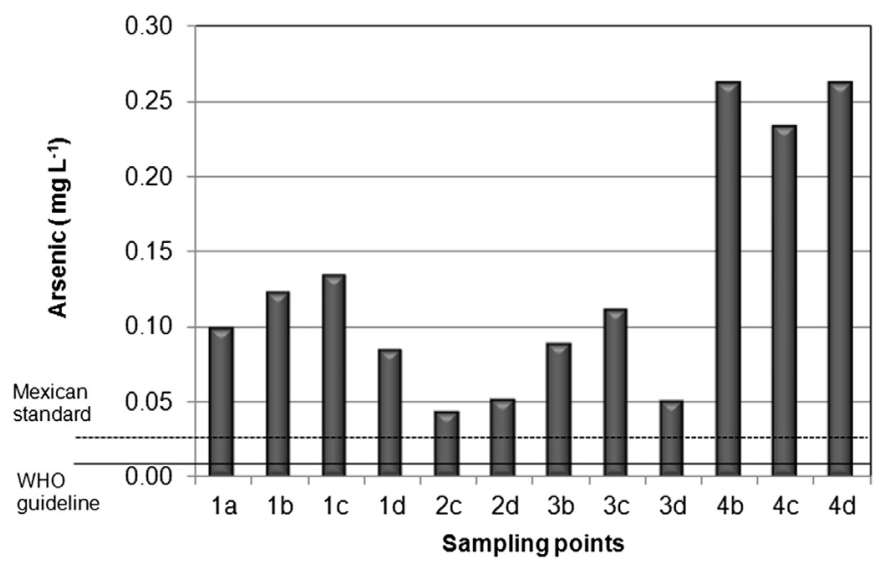

Fig. 4. Arsenic concentration in groundwater samples (1 Pajaro verde, 2 Presita, 3 Santiago, 4 Tlachichilpa). As concentrations were higher than Mexican drinking water standards and WHO (2004) guideline limits. 


\subsection{Tests of arsenic removal}

A preliminary test lasting 24 days ( $624 \mathrm{~h}$ ) was carried out using the three filter configurations. Table 2 shows the average water input and output parameters (with three replicates of each experiment) for this test. The overall efficiency of Experiment 1 using iron nails with $\mathrm{HNO}_{3} 4.8 \mathrm{~N}$ solution was $91.73 \%$, corresponding to

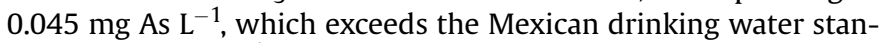
dard $\left(0.025 \mathrm{mg} \mathrm{L}^{-1}\right)$. The best results were obtained with Experiment 3, yielding arsenic concentrations below the Mexican standard of $0.025 \mathrm{mg} \mathrm{L}^{-1}$ and a maximum arsenic elimination efficiency of 95.45\%. Experiment 2 showed poorer efficiency as compared to Experiment 3, the former having a value of $72.73 \%$ and an arsenic concentration in the effluent of $0.03 \mathrm{mg} \mathrm{L}^{-1}$.

Based on these results, we conducted a long duration test of 105 days $(2520 \mathrm{~h})$ using the filter configuration from Experiments 2 and 3 .

Figs. 5 and 6 show the behavior of input and output arsenic concentrations for each water sampling point (P1, P2, P3, P4) according to the configuration of filters in Experiments 2 and 3. Arsenic removal for 105 days using commercial fiber treated with $\mathrm{HNO}_{3} 4.8 \mathrm{~N}$ solution (Experiment 2) was $238.90 \mathrm{mg} \mathrm{As} \mathrm{d}{ }^{-1}$, corresponding to $1327.71 \mathrm{mg} \mathrm{As} \mathrm{kg}^{-1}$. Arsenic removal with commercial fiber oxidized with $\mathrm{HCl} 2 \mathrm{~N}$ solution (Experiment 3) was $314.50 \mathrm{mg} \mathrm{As} \mathrm{d}^{-1}$, equivalent to $1734.67 \mathrm{mg} \mathrm{As} \mathrm{kg}^{-1}$.

The average values and the standard deviation of arsenic concentration (with three replicates of each experiment for each sampling point) for Experiment 2 with $\mathrm{HNO}_{3} 4.8 \mathrm{~N}$ solution and Experiment 3 with $\mathrm{HCl} 2 \mathrm{~N}$ solution are shown in Figs. 7 and 8, respectively. Fig. 9 shows the removal efficiency of the tests.

The overall removal efficiency for Experiment 2 was $72.48 \%$ (Fig. 9). The removal percentage for point P1-P2 was $28.44 \%$ (Fig. 9), corresponding to $0.078 \mathrm{mg} \mathrm{As} \mathrm{L}^{-1}$ (Fig. 7). The same percentage of $28.44 \%$ was obtained for point $\mathrm{P} 2-\mathrm{P} 3$, with a decrease in the concentration to $0.0047 \mathrm{mg} \mathrm{L}^{-1}$. And the efficiency for P3-P4 was $15.6 \%$ with a final arsenic concentration of $0.030 \mathrm{mg} \mathrm{As} \mathrm{L}^{-1}$, slightly higher than the value allowed by Mexican drinking water standards $\left(0.025 \mathrm{mg} \mathrm{L}^{-1}\right)$. This may be due to fewer active sites for adsorption, which requires more contact time (Debnath et al., 2003).

The overall removal percentage for Experiment 3 was 95.41\% (Fig. 9). For P1-P2, the removal efficiency was $75.23 \%$ (Fig. 9), equivalent to $0.027 \mathrm{mg} \mathrm{As} \mathrm{L}^{-1}$ (Fig. 7), slightly higher than the Mexican drinking water standard. Efficiency for P2-P3 was 5.5\% removal for an As concentration of $0.021 \mathrm{mg} \mathrm{L}^{-1}$, which meets drinking water standards. And for P3-P4, the removal efficiency was $14.68 \%$ with an As residual concentration of $0.005 \mathrm{mg} \mathrm{As}^{-1}$, which is below the allowable value established by Mexican drinking water standards.

Table 2

Average characteristics of the raw and treated effluent water and overall efficiency of the experiments (Period $=26$ days).

\begin{tabular}{|c|c|c|c|c|c|}
\hline \multirow[t]{3}{*}{ Parameters } & \multirow[t]{3}{*}{ Raw water } & \multirow{2}{*}{$\begin{array}{l}\text { Iron nails } \\
\left(\mathrm{HNO}_{3} 4.8 \mathrm{~N}\right)\end{array}$} & \multicolumn{2}{|c|}{ Commercial fiber } & \multirow{3}{*}{$\begin{array}{l}\text { Mexican } \\
\text { standards }\end{array}$} \\
\hline & & & $\left(\mathrm{HNO}_{3} 4.8 \mathrm{~N}\right)$ & $(\mathrm{HCl} 2 \mathrm{~N})$ & \\
\hline & & Exp. 1 & Exp. 2 & Exp. 3 & \\
\hline $\mathrm{EC}\left(\mu \mathrm{s} \mathrm{cm}^{-1}\right)$ & 447 & 424 & 466 & 450 & - \\
\hline $\mathrm{pH}$ & 7.6 & 8.55 & 8.60 & 8.6 & $6.5-8.5$ \\
\hline Arsenic (mg L $\left.{ }^{-1}\right)$ & 0.11 & 0.045 & 0.03 & 0.005 & 0.025 \\
\hline Turbidity (NTU) & 5.06 & 9 & 1.50 & 0.79 & 5 \\
\hline Color (UPt-Co) & 7.0 & 20 & 13 & 6.21 & 20 \\
\hline $\mathrm{Fe}\left(\mathrm{mg} \mathrm{L}^{-1}\right)$ & 0.035 & 0.57 & 0.16 & 0.05 & 0.30 \\
\hline Arsenic removal (\%) & & 59.00 & 72.73 & 95.45 & \\
\hline
\end{tabular}

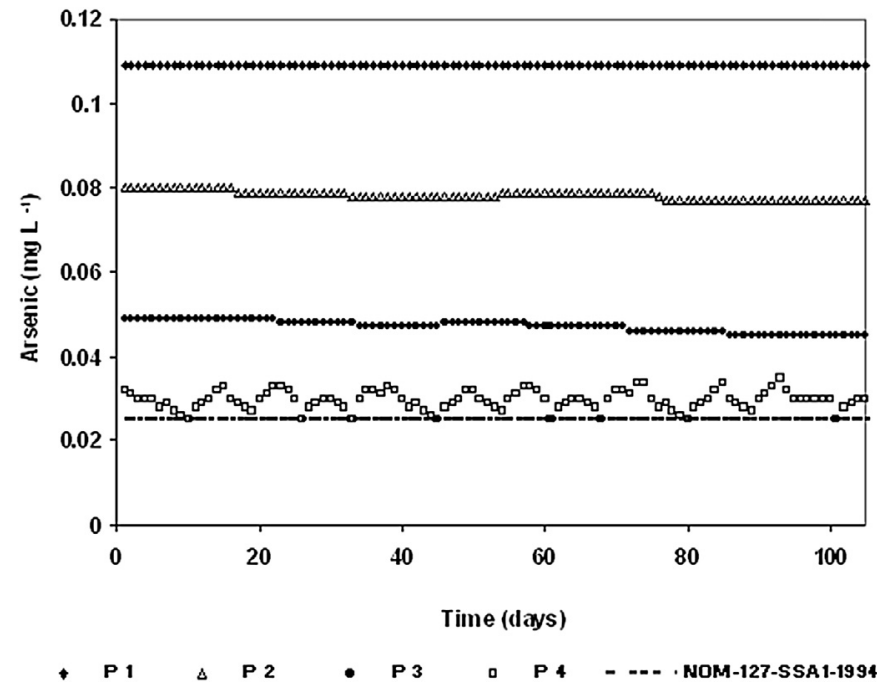

Fig. 5. Arsenic concentration in the effluent of Experiment 2 using a commercial fiber bed oxidized with $\mathrm{HNO}_{3} 4.8 \mathrm{~N}$ over a 105-day operation. $\mathrm{As}_{\text {initial: }} 0.11 \mathrm{mg} \mathrm{L} \mathrm{L}^{-1}$.

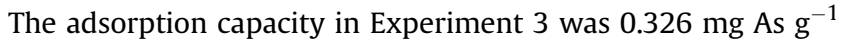
with a commercial fiber oxidized with $\mathrm{HCl} 2 \mathrm{~N}$ solution, which is

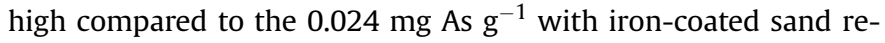
ported by Vaishya and Agarwal (1993) and the values of 0.043 and

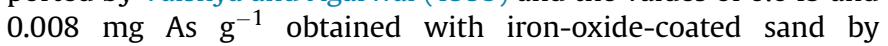
Thirunavukkarasu et al. (2001) and Thirunavukkarasu et al. (2003), respectively.

As $(\mathrm{V})$ removal by iron is based on a reduction process given by the following equations (at $\mathrm{pH}=8.5$ ) (Melitas et al., 2002):

$\mathrm{HAsO}_{4}^{2-}+3 \mathrm{H}^{+}+2 \mathrm{e}-\Leftrightarrow \mathrm{AsO}_{2}^{-}+2 \mathrm{H}_{2} \mathrm{O}$

$\mathrm{FeHAsO}_{4}^{2-}+3 \mathrm{H}^{+}+2 \mathrm{e}-\Leftrightarrow \mathrm{FeAsO}_{2}^{-}+2 \mathrm{H}_{2} \mathrm{O}$

The formation of a film adhesion to metal was observed during contact time. Although chemical stoichiometry studies were not conducted of the material that formed, this material could be $\mathrm{FeAsO}_{4} \cdot 2 \mathrm{H}_{2} \mathrm{O}$ (iron arsenate) considering the conditions under which the experiment was performed and the color of the

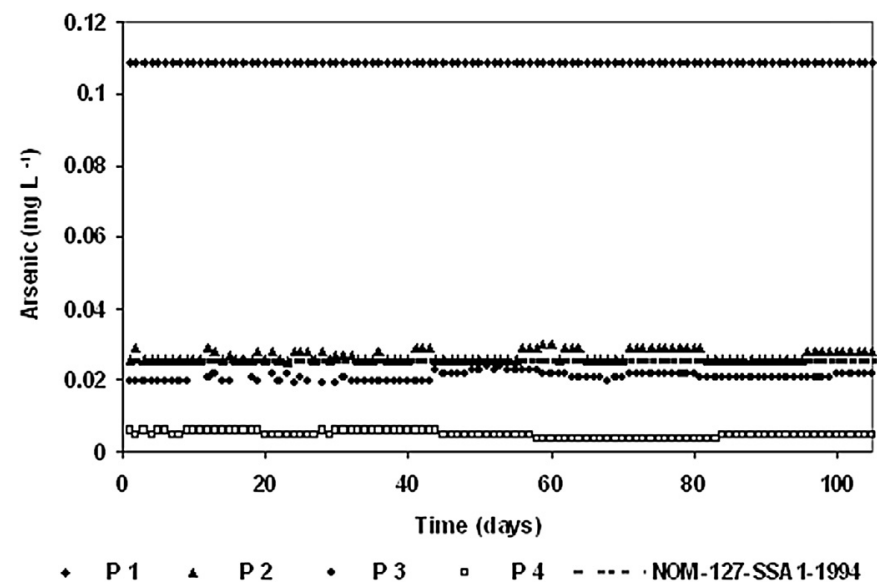

Fig. 6. Arsenic concentration in the effluent of Experiment 3 using a commercial fiber bed oxidized with $\mathrm{HCl} 2 \mathrm{~N}$ over a 105-day operation. As $\mathrm{s}_{\text {initial }}$ : $0.11 \mathrm{mg} \mathrm{L}^{-1}$. 


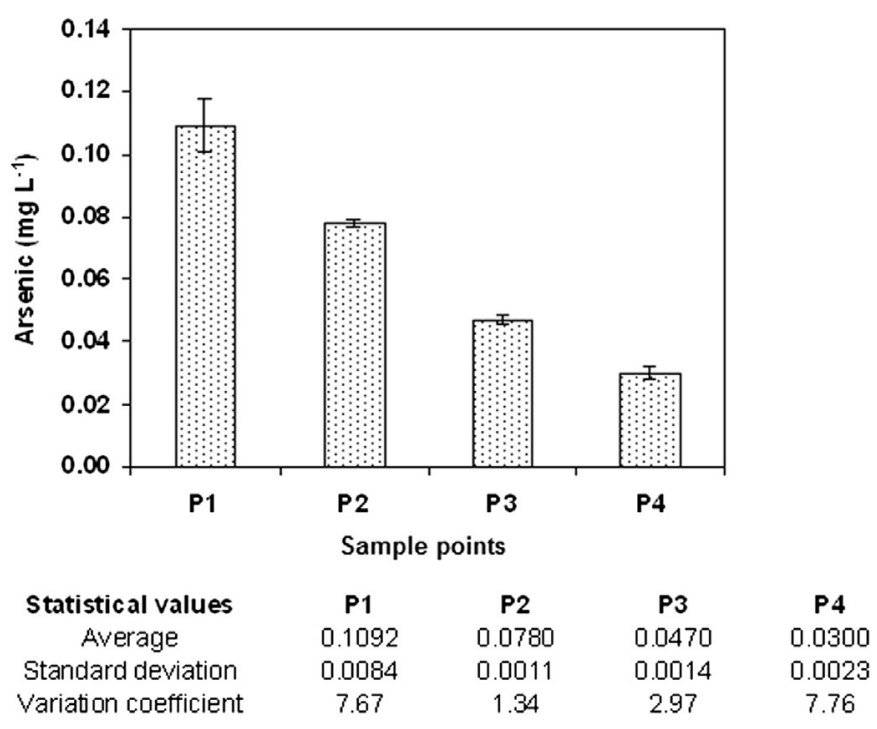

Fig. 7. Arsenic concentration in each sample point for Experiment 2 using a commercial fiber bed oxidized with $\mathrm{HNO}_{3} 4.8 \mathrm{~N}$.

precipitate. Based on the Eh-pH diagram of the As- $\mathrm{H}_{2} \mathrm{O}$ and $\mathrm{Fe}-$ $\mathrm{H}_{2} \mathrm{O}$ systems, the predominant species were $\mathrm{Fe}(\mathrm{OH})_{3}$ and $\mathrm{H}_{2} \mathrm{AsO}_{4}{ }^{-}$.

$\mathrm{FeAsO}_{4} \cdot 2 \mathrm{H}_{2} \mathrm{O}+\mathrm{H}_{2} \mathrm{O} \Leftrightarrow \mathrm{H}_{2} \mathrm{AsO}_{4}^{-}+\mathrm{Fe}(\mathrm{OH})_{3}+\mathrm{H}^{+}$

Table 3 presents the characteristics of raw and treated water from Experiment 3, observing that all parameters met Mexican drinking water standards.

\section{Conclusions}

Preliminary results from the Huautla Mining District showed that groundwater pooled in the workings was contaminated by arsenic and other toxic metals. As, $\mathrm{Fe}, \mathrm{Mn}, \mathrm{Pb}$ and $\mathrm{Cd}$ concentrations were higher than WHO and Mexican drinking water standards. The

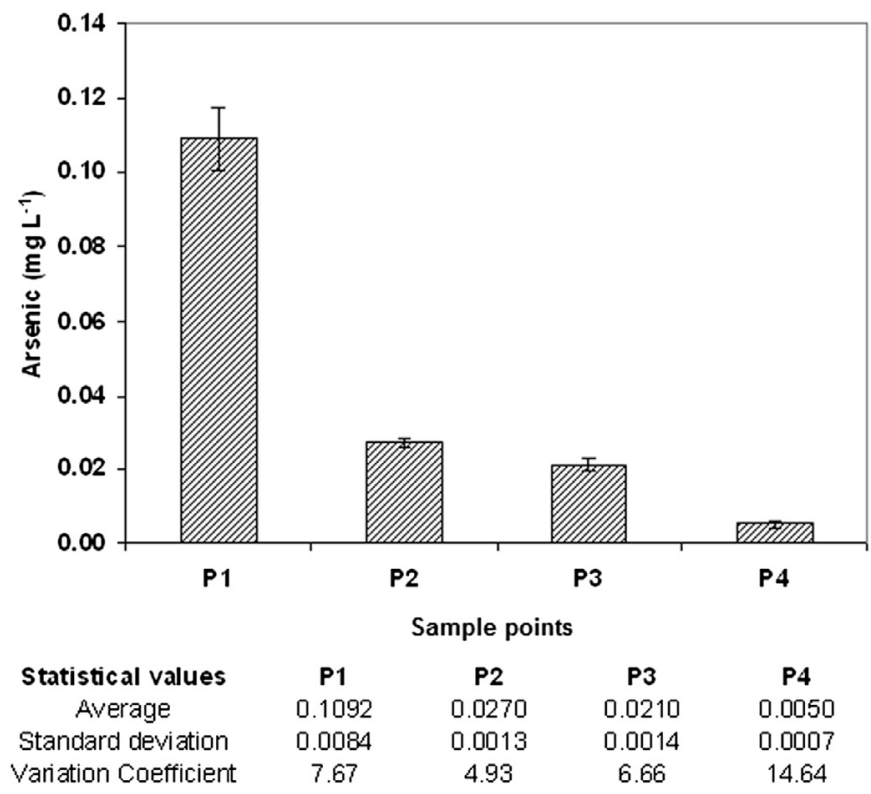

Fig. 8. Arsenic concentration in each sample point for Experiment 3 using a commercial fiber bed oxidized with $\mathrm{HCl} 2 \mathrm{~N}$.

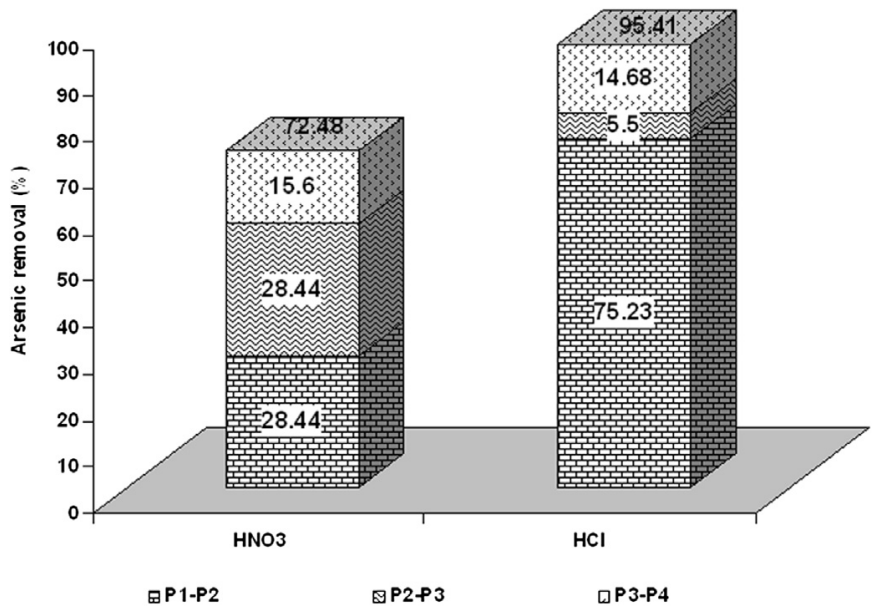

Fig. 9. Removal efficiencies of As for Experiment 2 (oxidized with $\mathrm{HNO}_{3}$ ) and 3 (oxidized with $\mathrm{HCl}$ ).

high dissolved arsenic concentration and the presence of silica and bicarbonate suggest competition for adsorption sites. This geochemical process could be responsible for arsenic enrichment in the groundwater.

In relation to the arsenic-exposed population, about half the surveyed sample in Huautla was exposed to significant amounts of arsenic in drinking water. Moreover, the entire population was exposed to the metalloid through water used for food preparation.

Tests of a small household filter demonstrated that it could be a viable low-cost solution considering the prevailing conditions in

Table 3

Average characteristics of the raw and treated effluent water for Experiment 3 (Period $=105$ days $)$.

\begin{tabular}{|c|c|c|c|c|}
\hline Parameter & & $\begin{array}{l}\text { Mexican } \\
\text { standards }\end{array}$ & $\begin{array}{l}\text { Influent P1 } \\
\text { (raw water) }\end{array}$ & $\begin{array}{l}\text { Effluent P4 } \\
\text { (HCl 2N) }\end{array}$ \\
\hline Color & $\mathrm{U} \mathrm{Pt}-\mathrm{Co}$ & 20 & 7.00 & 6.21 \\
\hline Turbidity & NTU & 5.00 & 5.06 & 0.79 \\
\hline $\mathrm{pH}$ & & $6.5-8.5$ & 7.67 & 8.60 \\
\hline $\begin{array}{l}\text { Total } \\
\quad \text { Suspended } \\
\text { Solids }\end{array}$ & $\mathrm{mg} \mathrm{L}^{-1}$ & - & 15.0 & 13.0 \\
\hline $\begin{array}{l}\text { Total } \\
\text { Dissolved } \\
\text { Solids }\end{array}$ & $\mathrm{mg} \mathrm{L}^{-1}$ & 1000 & 396 & 254 \\
\hline $\mathrm{HCO}_{3}^{-}$ & $\mathrm{mg} \mathrm{L}^{-1}$ & - & 248 & 241 \\
\hline Hardness & $\mathrm{mg} \mathrm{L}^{-1}$ & 500 & 197 & 169 \\
\hline $\mathrm{N}-\mathrm{NO}_{2}^{-}$ & $\mathrm{mg} \mathrm{L}^{-1}$ & 0.5 & $<0.12$ & $<0.12$ \\
\hline $\mathrm{N}-\mathrm{NO}_{3}^{-}$ & $\mathrm{mg} \mathrm{L}^{-1}$ & 10 & 1.42 & 1.35 \\
\hline $\mathrm{SO}_{4}^{2-}$ & $\mathrm{mg} \mathrm{L}^{-1}$ & 400 & 11.5 & 10.67 \\
\hline $\mathrm{F}^{-}$ & $\mathrm{mg} \mathrm{L}^{-1}$ & 1.5 & 0.51 & 0.48 \\
\hline $\mathrm{PO}_{4}^{3-}$ & $\mathrm{mg} \mathrm{L}^{-1}$ & - & $<1.04$ & $<1.04$ \\
\hline $\mathrm{Cl}^{-}$ & $\mathrm{mg} \mathrm{L}^{-1}$ & 250 & 4.43 & 4.28 \\
\hline As total & $\mathrm{mg} \mathrm{L}^{-1}$ & 0.025 & 0.110 & 0.005 \\
\hline $\mathrm{Cd}$ & $\mathrm{mg} \mathrm{L}^{-1}$ & 0.005 & $<0.001$ & $<0.02$ \\
\hline $\mathrm{Ca}$ & $\mathrm{mg} \mathrm{L}^{-1}$ & - & 49.54 & 29.38 \\
\hline $\mathrm{Al}$ & $\mathrm{mg} \mathrm{L}^{-1}$ & 0.20 & $<0.005$ & $<0.005$ \\
\hline $\mathrm{Fe}$ & $\mathrm{mg} \mathrm{L}^{-1}$ & 0.30 & $<0.05$ & 0.14 \\
\hline $\mathrm{Cu}$ & $\mathrm{mg} \mathrm{L}^{-1}$ & 2.0 & $<0.05$ & $<0.05$ \\
\hline $\mathrm{Cr}$ & $\mathrm{mg} \mathrm{L}^{-1}$ & 0.06 & $<0.05$ & $<0.05$ \\
\hline $\mathrm{Mg}$ & $\mathrm{mg} \mathrm{L}^{-1}$ & - & 17.36 & 16.97 \\
\hline Mn & $\mathrm{mg} \mathrm{L}^{-1}$ & 0.15 & $<0.05$ & $<0.05$ \\
\hline $\mathrm{Pb}$ & $\mathrm{mg} \mathrm{L}^{-1}$ & 0.01 & $<0.005$ & $<0.005$ \\
\hline K & $\mathrm{mg} \mathrm{L}^{-1}$ & - & 2.36 & 2.15 \\
\hline Si & $\mathrm{mg} \mathrm{L}^{-1}$ & - & 14.31 & 13.98 \\
\hline $\mathrm{Ni}$ & $\mathrm{mg} \mathrm{L}^{-1}$ & - & $<0.05$ & $<0.05$ \\
\hline $\mathrm{Zn}$ & $\mathrm{mg} \mathrm{L}^{-1}$ & 5.0 & $<0.10$ & $<0.10$ \\
\hline $\mathrm{Na}$ & $\mathrm{mg} \mathrm{L}^{-1}$ & 200 & 32.97 & 31.93 \\
\hline
\end{tabular}


rural areas, where centralized water supply systems are absent. A household filter with appropriate commercial fiber had great potential for producing water with low dissolved arsenic contents (average output $<0.015 \mathrm{mg} \mathrm{L}^{-1}$ versus $0.11 \mathrm{mg} \mathrm{L}^{-1}$ groundwater arsenic concentrations). This technology is expected to continue to improve, as it is adapted to rural environments.

\section{Acknowledgments}

This study was supported by the Consejo Nacional de Ciencia y Tecnología, CONACYT (project SEP-CONACYT 2004-C01-47076). The authors wish to thank SGM (Servicio Geológico Mexicano) for the documents provided for this investigation.

\section{References}

APHA, AWWA, WEF, 2005. Standard Methods for the Examination Water and Wastewater, 21th ed. APHA, AWWA, WEF, Washington, D.C.

Appelo, C.A.J., Potsm, D., 2005. Geochemistry, Groundwater and Pollution, second ed. Balkema, Rotterdam.

Armienta, M.A., Segovia, N., 2008. Arsenic and fluoride in the groundwater of Mexico. Environ. Geochem. Heal. 30, 345-353.

Berg, M., Luzi, S., Kim-Trang, P.T., Viet, P.H., Giger, W., Stübenm, D., 2006. Arsenic removal from groundwater by household sand filters: comparative field study, model calculations, and health benefits. Environ. Sci. Technol. 40, 5567-5573.

Camprubi, A., Albison, T., 2006. Depósitos hidrotermales en México: actualización de su conocimiento y reclasificación empírica. Boletín Soc. Geol. Mex. LVIII (1), 27-81. Volumen Conmemorativo del Centenario.

Debnath, S., Dey, S., Ghosh, U.C., Manna, B., 2003. Removal of arsenic from groundwater using crystalline hydrous ferric oxide (CHFO). Water Qual. Res. J. Can. 38 (1), 193-210.

Driehaus, W., 2002. Arsenic removal - experience with the GEH process in Germany. Water Sci. Technol. Water Supply 2 (2), 275-280.

Esteller, M.V., Domínguez-Mariani, E., Garrido, S.E., Avilés, M., 2010. Arsenic in groundwater at an abandoned mining area in Central Mexico. In: Birkle, P., Torres-Alvarado, I.S. (Eds.), Water Rock Interaction. CRC Press Taylor \& Francis, Leiden, The Netherlands, pp. 519-522.

Gao, X., Wang, Y., Hu, Q., Su, Ch, 2011. Effects of anion competitive adsorption on arsenic enrichment in groundwater. J. Environ. Sci. Heal. A 46, 471-479.

Garrido, S., Avilés, M., Ramírez, A., Calderón, C., Ramírez-Orozco, A., Nieto, A., Shelp, G., Seed, L., Cebrian, M., Vera, E., 2009. Arsenic removal from water of Huautla, Morelos, Mexico using capacitive deionization. In: Bundschuh, J., Armienta, M.A., Birkle, P., Bhattacharya, P., Matschullat, J., Mukherjee, A.B. (Eds.), Natural Arsenic in Groundwater of Latin America, vol 1. CRC Press Taylor \& Francis, Leiden, The Netherlands, pp. 665-676.

Giles, D.E., Mohapatra, M., Issa, T.B., Anand, S., Singh, P., 2011. Iron and aluminium based adsorption strategies for removing arsenic from water. J. Environ. Manag. 92, 3011-3022.

Hussam, A., Munir, A.K.M., 2007. A simple and effective arsenic filter based on composite iron matrix: development and deployment studies for groundwater of Bangladesh. J. Environ. Sci. Heal. A 42, 1869-1878.

Iavazzo, P., Ducci, D., Adamo, P., Trifuoggi, M., Migliozzi, A., Boni, M., 2012. Impact of past mining activity on the quality of water and soil in the High Mouloya Valley (Morocco). Water Air Soil Pollut. 223, 573-589.
Leupin, O.X., Hug, S.J., 2005. Oxidation and removal of arsenic (III) from aerated groundwater by filtration through sand and zero-valent iron. Water Res. 39, $1729-1740$.

MacNeil, L.S., Chen, H., Edwards, M., 2002. Aspects of occurrence, health and treatment. In: Frankenberger Jr., W. (Ed.), Environmental Chemistry of Arsenic. Marcel Dekker, New York, pp. 141-153.

Melitas, N., Wang, J.P., Conklin, M., O’Day, P., Farrell, J., 2002. Understanding soluble arsenate removal kinetics by zerovalent iron. Environ. Sci. Technol. 36, 31883193.

Mohan, D., Pittman, C.H., 2007. Arsenic removal from water/wastewater using adsorbents. A critical review. J. Hazard. Mat 142, 1-53.

Ngai, T.K.K., Murcott, S., Shrestha, R.R., Dangol, B., Maharjan, M., 2006. Development and dissemination of KanchanTM arsenic filter in rural Nepal. Water Sci. Tech. Water Supply 6 (3), 137-146.

Ngai, T.K.K., Shresta, R.R., Dangol, B., Maharjan, M., Murcott, S.E., 2007. Design for sustainable development-Household drinking water filter for arsenic and pathogen treatment in Nepal. J. Environ. Sci. Heal. A 42, 1879-1888.

NOM 127-SSA1-1994, 22 de noviembre de 2000. Modificación a la Norma Oficial Mexicana. Salud Ambiental. Agua para uso y consumo humano. Límites permisibles de calidad y tratamientos a que debe someterse el agua para su potabilización. In: Diario Oficial de la Federación.

NOM 230-SSA1-2002, 12 de julio de 2005. Norma Oficial Mexicana Salud Ambiental. Agua para uso y consumo humano. Requisitos sanitarios que se deben cumplir en los sistemas de abastecimiento públicos y privados durante el manejo del agua. Procedimientos sanitarios para el muestreo. In: Diario Oficial de la Federación.

Parkhurst, D.L., Appelo, C.A.J., 1999. PHREEQC US Geol. Surv. Water Resources Investigations Report, pp. 99-4259.

Petrusevski, B., Sharma, S.,K., Kuis, F., Omeruglu, P., Schippers, J.C., 2002. Family filter with iron-coated sand: solution for arsenic rural areas. Water Sci. Tech. Water Supply 2 (5-6), 127-133.

Pokhrel, D., Viraraghavan, T., 2009. Biological filtration for removal of arsenic fro drinking water. J. Environ. Manag. 90, 1956-1961.

Rodriguez, R., Ramos, J.R., Armienta, M.A., 2004. Groundwater arsenic variations: the role of local geology and rainfall. Appl. Geochem. 19, 245-250.

Sarkar, S., Blaney, L.M., Gupta, A. Ghosh, D. Sengupta, A.K., 2008. Arsenic removal from groundwater and its containment in a rural environment: validation of a sustainable approach. Environ. Sci. Technol. 42, 4268-4273.

Schulze, G., 1959. Contribuciones al estudio petrológico y mineralógico económico del mineral de Huautla, Morelos. Archivo Técnico. Servicio Geológico Mexicano TI 170001.

Seiler, K.P., 2004. Mobility of arsenic in sediments with high buffering capacity. In: Proc. Int. Congress XXXIII IAH - $7^{\circ}$ ALHSUD. Groundwater Flow Understanding from Local to Regional Scales. Zacatecas City, Mexico, 11-15 October 1996. IAH (International Association of Hydrogeologists).

Smedley, P.L., Kinniburgh, D.G., 2002. A review of the source, behaviour and distribution of arsenic in natural waters. Appl. Geochem. 17, 517-568.

Thirunavukkarasu, O.S., Viraraghaven, T., Subramanian, K.S., 2001. Removal of arsenic in drinking water by iron oxide-coated sand and ferrihydrite batch studies. Water Qual. Res. J. Can. 36 (1), 55-70.

Thirunavukkarasu, O.S., Viraraghaven, T., Subramanian, K.S., 2003. Arsenic removal from drinking water using iron oxide-coated sand. Water Air Soil Pollut. 142, 95-111.

US EPA Environmental Protection Agency, 1991. Guidelines for Development Toxicity Risk Assessment, (FRL-4038-3). Washington, D.C. USA, p. 71.

Vaishya, R.C., Agarwal, I.C., 1993. Removal of arsenic (III) from contaminated ground waters by Ganga sand. J. Indian Water Works Assoc. 25 (3), 249-253.

WHO World Health Organization, 2004. Guidelines for Drinking Water Quality. World Health Organization, Geneve, Switzerland. 